\title{
Estimation of Mycotoxin Multiple Contamination in Mexican Hybrid Seed Maize by HPLC-MS/MS
}

\author{
Silvia Denise Peña Betancourt ${ }^{1 *}$, Benjamín Valladares Carranza², \\ Eduardo Posadas Manzano ${ }^{3}$ \\ ${ }^{1}$ Department of Animal and Agricultural Production, Laboratory of Toxicology, UAM-X, México, D.F., México \\ ${ }^{2}$ Center of Research and Studies in Animal Health, FMVZ, UAEM, Toluca, México \\ ${ }^{3}$ Department of Animal Ruminants, Faculty of Veterinary Medicine, UNAM, México, D.F., México \\ Email: ${ }^{*}$ s.denisepena@gmail.com
}

Received 4 August 2015; accepted 23 September 2015; published 29 September 2015

Copyright (C) 2015 by authors and Scientific Research Publishing Inc.

This work is licensed under the Creative Commons Attribution International License (CC BY).

http://creativecommons.org/licenses/by/4.0/

(c) (i) Open Access

\section{Abstract}

In Mexico, the presence of mycotoxins in chemical treated seed maize by sowing is not well known, despite the need to improve the quality and corn safe for human consumption. It collected twentyfive genotypes maize samples from Morelos State in the spring of 2013, all of them treated with synthetic colors (pink, green, yellow), fungicides and insecticides. Two samples (synthetic seed and hybrid commercial) were selected for analysis of twenty-two mycotoxins by LC-MS/MS and $\mathrm{AFB}_{1}$ determination by liquid chromatography and fluorescence detection (HPLC-FLD). The results of the 25 samples showed the presence of Aflatoxin $B_{1}$ in $25 \%$ of samples in a ranged concentration between 2 to $6 \mu \mathrm{g} \cdot \mathrm{kg}^{-1}$, and average of $4.1^{-1} \mu \mathrm{g} \cdot \mathrm{kg}$, which were within the allowed limits by national and international legislation. Twenty-two mycotoxins were found in levels ranging between 791.7 and $891.2 \mu \mathrm{g} \cdot \mathrm{kg}$. The content average in both samples was for total aflatoxins (AFB ${ }_{1}$, $\mathrm{AFB}_{2}, \mathrm{AFG}_{1}, \mathrm{AG}_{2}$ ) of $16.95 \mu \mathrm{g} \cdot \mathrm{kg}$, with $\mathrm{G}$ aflatoxins the most prevalence. Twelve trichothecenes (Nivalenol, Neosolanol, Fusarenone $X$, DAS, $\mathrm{HT}$-2, $\mathrm{FB}_{1}, \mathrm{FB}_{2}, \mathrm{FB}_{3}$, T-2, Zearalenone, ZEA2, ZEA3) were in a level of $292.7 \mu \mathrm{g} \cdot \mathrm{kg}^{-1}$, Enniantine $8.6 \mu \mathrm{g} \cdot \mathrm{kg}^{-1}$, Sterigmatocystin $6.5 \mu \mathrm{g} \cdot \mathrm{kg}^{-1}$, Roquefortine $\mathrm{C}, 2.9$ $\mu \mathrm{g} \cdot \mathrm{kg}^{-1}$. Ochratoxin $8.8 \mu \mathrm{g} \cdot \mathrm{kg}^{-1}$ and Mycophenolic acid at $535 \mu \mathrm{g} \cdot \mathrm{kg}^{-1}$ were the highest content. The synthetic color present in seeds analyzed inhibited a good purification in the extracted mycotoxin by optimizing the step in HPLC-MS/MS quantification system. The information generated in this study would be useful in breeding programs in order to improve the sanitary quality and also to investigate the final contamination of agricultural products with multiple mycotoxin contamination.

\footnotetext{
${ }^{*}$ Corresponding author.
}

How to cite this paper: Peña Betancourt, S.D., Valladares Carranza, B. and Posadas Manzano, E. (2015) Estimation of Mycotoxin Multiple Contamination in Mexican Hybrid Seed Maize by HPLC-MS/MS. Agricultural Sciences, 6, 1089-1097. 


\section{Keywords}

\section{Maize Seed, Warehouse, Moulds, Mycotoxins, HPLC, MS/MS}

\section{Introduction}

In Mexico, maize (corn) is the most produced and consumed cereal, like tortilla, an adult may consume 360 g/day [1]. Producer's corn requires protecting seed before planting; using fungicides, insecticides and synthetic dyes as yellow, green and pink to prevent consumption by people [2]. Studies show that a co-occurrence of fungus and mycotoxins in harvest and post-harvest maize is possible around the world [3], but there is not enough information in the chemically treated seed previously sowing. Mycotoxins are a group of secondary metabolites produced by different fungus in maize, one of the most toxic compounds known for humans [4]. The aflatoxin $\mathrm{B}_{1}\left(\mathrm{AFB}_{1}\right)$, is carcinogenic; Ocratoxine $\mathrm{A}(\mathrm{OTA})$ and Fumonisins are genotoxic, immunotoxic and recently classified by International Agency for Research on Cancer (IARC) in 2B group of substances possible to human carcinogenic [5] [6]. Esterigmatocistine (ST) is hepatotoxic; in general most of mycotoxins are immunosuppressive [7], indeed it is important to know their exposure since a chronic exposure to low levels can give diseases like cancers [8], additionally it is not well known about the possible interaction between multiple mycotoxins [9]; and on the other hand, fungus and mycotoxins would remain in environment (air, soil, water), due to their stability against degradation [10]-[12]. Among the identified fungus in post-harvest are Aspergillus flavus, Aspergillus parasiticus, Aspergillus ochraceus which are producers of Sterigmatocystin, Aflatoxin $\mathrm{B}_{1}, \mathrm{~B}_{2}, \mathrm{G}_{1}$ and $\mathrm{G}_{2}$ and Ochratoxin A; Penicillium spp, producer of Roquefortine $C$ and Mycophenolic acid, Fusarium verticilliodes (Zearalenone, Deoxynivalenol, DAS, Nivalenol, T-2, HT-2, Fusarenona X, Fumonisin $\mathrm{B}_{1}, \mathrm{FB}_{2}, \mathrm{FB}_{3}$ ) and Alternaria alternate, Alternariol (AL) and Methyl ethyl alternariol (AM) [13]. Various methods have been used to isolate and quantify the levels of mycotoxins, such as liquid chromatography with fluorescense detector (HPLC/ FLD), high performance liquid chromatography coupled to system triple-quadruple mass spectrometer (HPLCMS/MS). In Mexico official tests to determine the presence of $\mathrm{AFB}_{1}$ and total aflatoxins $\left(\mathrm{AFB}_{1}, \mathrm{AFB}_{2}, \mathrm{AFG}_{1}\right.$, $\mathrm{AFG}_{2}, \mathrm{AFM}_{1}$ ) are HPLC/FLD [14] [15]. The National regulation sets a maximum level of $20 \mu \mathrm{g} / \mathrm{kg}$ and $0.05 \mu \mathrm{g} /$ $\mathrm{kg} \mathrm{AFB}{ }_{1}$ and $\mathrm{AFM}_{1}$ in raw maize and milk [16]. In some countries more of 20 mycotoxins are subject to legal guidance and regular monitoring [17]-[19], like in Food Analysis Laboratory in Ghent University at Belgium, which make a survey of 35 mycotoxins and regulated $\mathrm{AFB}_{1}$ and DON in $5 \mu \mathrm{g} \cdot \mathrm{kg}$, total Fumonisins at $50 \mu \mathrm{g} \cdot \mathrm{kg}^{-1}$, zearalenone at $500 \mu \mathrm{g} \cdot \mathrm{kg}^{-1}$ and Ochratoxin A in $5 \mu \mathrm{g} \cdot \mathrm{kg}^{-1}$ [20]. This study was designed to analyze $\mathrm{AFB}_{1}$ as well as twenty-two mycotoxins in sowing maize seed in one synthetic variety and commercial hybrid maize, both adapted to a tropical region in the country.

\section{Materials and Methods}

\subsection{Collection of Samples}

25 genotypes of white and yellow hybrid maize were collected directly (about $1 \mathrm{~kg}$ each) in experimental station, Zacatepec Morelos State in the spring of 2013. It is a region geographically defined by the coordinates of $18^{\circ} 37^{\prime}$ and $18^{\circ} 41^{\prime}$ north latitude, $99^{\circ} 10^{\prime}$ and $99^{\circ} 14^{\prime}$ west longitude; with warm humid climate; the annual average rainfall is $892 \mathrm{~mm}$ and the minimum and maximum temperatures are $24^{\circ} \mathrm{C}$ and $40^{\circ} \mathrm{C}$ in an altitude between 900 to $1200 \mathrm{~m}$. The comprised genotypes of maize adapted to temperate and tropical regions, all of them treated with colors (pink, green, yellow), fungicides and insecticides. These two samples were chosen based on their significance, one of two in terms of synthetic variety and the other for production and protein value, both sample were trilinear varieties.

\subsection{Chemical, Reagents and Materials}

All mycotoxins standards, solvents and material used like methanol, acetonitrile HPLC grade from Merck Company were purchased from Sigma-Aldrich Company, USA.

\subsection{Stock Solutions}

The mycotoxin standard stock solutions were prepared weighting $1 \mathrm{mg}$ of $\mathrm{AFB}_{1}$, Sterigmatocistine and Zeara- 
lenone, $5 \mathrm{mg}$ each of T-2 toxin Neosolaniol; $10 \mathrm{mg}$ of Deoxynivalenol, Nivalenol and Fusarenone X. Each of them were placed in a $50 \mathrm{~mL}$ volumetric flask and dissolved by the addition of acetonitrile.

\section{4. $\mathrm{AFB}_{1}$ Extraction}

Aflatoxin $\mathrm{B}_{1}$ was held at the Laboratory Toxicology at UAM Xochimilco by a liquid chromatography and fluorescence detection (FLD), using Varian Polaris equipment. The method according to the official method [21] was used. In a dried and ground sample (50 g) was mixed with $100 \mathrm{~mL}$ of $80 \%$ methanol in water (vol/vol) and shaken for $1 \mathrm{~h}$. The aflatoxin $B_{1}$ was separated on an analytical reversed phase column C18 $(150 \mathrm{~mm} \times 4.6 \mathrm{~mm})$ 5 um particles. The mobile phase was composed of water/methanol/acetonitrile $(60: 20: 20 \mathrm{v} / \mathrm{v})$. Aflatoxin $\mathrm{B}_{1}$ detection was carried out at excitation $\lambda 360 \mathrm{~nm}$, and emission $\lambda 440 \mathrm{~nm}$ wavelengths, in a flow rate was $1 \mathrm{~mL}$ min of the mobil phase. Finally the retention time was calculated with five consecutive injections of $\mathrm{AFB}_{1}$ working solutions.

\subsection{Multiple Mycotoxin Extraction}

Twenty-two mycotoxins were performed according to the protocol of food analysis laboratory of the Faculty of Pharmacy of the Ghent University, Belgium by HPLC on tandem mass (LC-MS/MS) with ionization detection (Waters UPLC-Quattro Tandem Quadruple MS instrument). Briefly the procedure was taken a $2.5 \mathrm{~g}$ of milling sample extracted with acetonitrile/ $\mathrm{H}_{2} \mathrm{O}(95: 5 \mathrm{v} / \mathrm{v})+10 \mathrm{Mm}$ NH4-acetate in $\mathrm{pH} 3.0$, hexane defatting in a shaker by $60 \mathrm{~min}$, centrifugation $3000 \mathrm{rpm}$ for $15 \mathrm{~min}$, filtration $(0.25 \mu \mathrm{m})$, clean with tandem immunoassay column, the eluate was evaporated to dryness and redissolution with injection system, so finally made a $10 \mu \mathrm{L}$ injection to $\mathrm{LC} / \mathrm{MS} / \mathrm{MS}$.

\section{Results}

The average of multiple mycotoxins analysis in synthetic and hybrid commercial seed are summarized in Table 1. Total mycotoxins mean content was $556.9 \mu \mathrm{g} \cdot \mathrm{kg}^{-1}$, which is the first time that had been described in chemically treated seeds prior to its sowing in Mexico. Fumonisins concentration $\left(\mathrm{FB}_{1}, \mathrm{FB}_{2}\right.$ and $\left.\mathrm{FB}_{3}\right)$ was 134.3 $\mu \mathrm{g} \cdot \mathrm{kg}^{-1}$, while $\mathrm{FB}_{2}$ with the highest concentration of $67.4 \mu \mathrm{g} \cdot \mathrm{kg}^{-1}$, total aflatoxins ( $\mathrm{AFG}_{2}, \mathrm{AFG}_{1}, \mathrm{AFB}_{1}, \mathrm{AFB}_{2}$ ) in $16.9 \mu \mathrm{g} \cdot \mathrm{kg}^{-1}$, with $\mathrm{AG}_{2}$ the most important $\left(8.5 \mu \mathrm{g} \cdot \mathrm{kg}^{-1}\right)$, Ochratoxin A with $8.80 \mu \mathrm{g} \cdot \mathrm{kg}^{-1}$, Sterigmatocistine $6.50 \mu \mathrm{g} \cdot \mathrm{kg}^{-1}$, Roquefortine C $2.9 \mu \mathrm{g} \cdot \mathrm{kg}^{-1}$, Enniantine $8.65 \mu \mathrm{g} \cdot \mathrm{kg}^{-1}$, trichothecenes type A and B (NIV, NEO, FUSX, DAS, HT-2, T-2, Zearalenone, ZEA1, ZEA2) with a total levels of $197.4 \mu \mathrm{g} \cdot \mathrm{kg}^{-1}$ Alternariol 17.4 $\mu \mathrm{g} \cdot \mathrm{kg}^{-1}$ and Methyl Alternariol $16.7 \mu \mathrm{g} \cdot \mathrm{kg}^{-1}$.

In synthetic seed, the content of $\mathrm{FB}_{1}, \mathrm{FB}_{2}$ and $\mathrm{FB}_{3}$ were $33.3,66.1,29.9 \mu \mathrm{g} \cdot \mathrm{kg}^{-1}$ respectively, with a total of $129.3 \mu \mathrm{g} \cdot \mathrm{kg}^{-1}, \mathrm{AFG}_{2}, \mathrm{AFG}_{1}, \mathrm{AFB}_{1}$ and $\mathrm{AFB}_{2}$ in $8.5 \mu \mathrm{g} \cdot \mathrm{kg}^{-1}, 3.6 \mu \mathrm{g} \cdot \mathrm{kg}^{-1}, 1.7 \mu \mathrm{g} \cdot \mathrm{kg}^{-1}, 2.4 \mu \mathrm{g} \cdot \mathrm{kg}^{-1}$ respectively with a total of $16.2 \mu \mathrm{g} \cdot \mathrm{kg}^{-1}$, the Ochratoxin A in $8.70 \mu \mathrm{g} \cdot \mathrm{kg}^{-1}$, Sterigmatocistine $6.50 \mu \mathrm{g} \cdot \mathrm{kg}^{-1}$, Roquefortine C, $2.5 \mu \mathrm{g} \cdot \mathrm{kg}^{-1}$, Enniantine $8.60 \mu \mathrm{g} \cdot \mathrm{kg}^{-1}$, trichothecenes (Nivalenol, NEO, Fusarenone X, Diacetoxyscirpenol, HT-2, $\mathrm{T}-2$, Zearalenone, ZEA1, ZEA2) with a total content of $123.0 \mu \mathrm{g} \cdot \mathrm{kg}^{-1}$, Alternariol $14.7 \mu \mathrm{g} \cdot \mathrm{kg}^{-1}$ and Methyl Alternariol $15.3 \mu \mathrm{g} \cdot \mathrm{kg}^{-1}$.

In commercial hybrid seed, the content of $\mathrm{FB}_{1}, \mathrm{FB}_{2}$ and $\mathrm{FB}_{3}$ were $42 \mu \mathrm{g} \cdot \mathrm{kg}^{-1}, 68 \mu \mathrm{g} \cdot \mathrm{kg}^{-1}$ and $29.3 \mu \mathrm{g} \cdot \mathrm{kg}^{-1} \mathrm{re}-$ spectively with a total of $139.3 \mu \mathrm{g} \cdot \mathrm{kg}^{-1}, \mathrm{AFG}_{2}, \mathrm{AFG}_{1}, \mathrm{AFB}_{1}$ and $\mathrm{AFB}_{2}$ in $9.2 \mu \mathrm{g} \cdot \mathrm{kg}^{-1}, 3.6 \mu \mathrm{g} \cdot \mathrm{kg}^{-1}, 2.4 \mu \mathrm{g} \cdot \mathrm{kg}^{-1}$ and $2.5 \mu \mathrm{g} \cdot \mathrm{kg}^{-1}$ with a total of $17.7 \mu \mathrm{g} \cdot \mathrm{kg}$, Ochratoxin A $8.90 \mu \mathrm{g} \cdot \mathrm{kg}$, Sterigmatocistine $6.50 \mu \mathrm{g} \cdot \mathrm{kg}$, Roquefortine C, $3.3 \mu \mathrm{g} \cdot \mathrm{kg}^{-1}$, Eniantine $8.70 \mu \mathrm{g} \cdot \mathrm{kg}^{-1}$, trichothecenes (NIV, NEO, FUSX, DAS, HT-2, T-2, ZEA1, ZEA2, ZEA3) with $171.8 \mu \mathrm{g} \cdot \mathrm{kg}^{-1}$, Alternariol $20.1 \mu \mathrm{g} \cdot \mathrm{kg}^{-1}$ and Methyl Alternariol $18.1 \mu \mathrm{g} \cdot \mathrm{kg}^{-1}$. Figures 1-8 show the chromatograms from LC-MS/MS detected multiple mycotoxins in synthetic and commercial hybrid seed.

Table 1. Mycotoxins contamination in seed samples studies.

\begin{tabular}{|c|c|c|c|c|c|c|c|c|}
\hline Sample & $\begin{array}{l}\text { Fumonisin } \\
\left(\mu \mathrm{g} \cdot \mathrm{kg}^{-1)}\right.\end{array}$ & $\begin{array}{c}\text { OTA } \\
\left(\mu \mathrm{g} \cdot \mathrm{kg}^{-1}\right)\end{array}$ & $\begin{array}{l}\text { Total AF } \\
\left(\mu \mathrm{g} \cdot \mathrm{kg}^{-1}\right)\end{array}$ & $\begin{array}{c}\mathrm{AB} 1 \\
\left(\mu \mathrm{g} \cdot \mathrm{kg}^{-1)}\right.\end{array}$ & $\begin{array}{l}\text { Tricothecenes } \\
\left(\mu \mathrm{g} \cdot \mathrm{kg}^{-1}\right)\end{array}$ & $\begin{array}{l}\text { Mycophenolic } \\
\text { acid }\left(\mu \mathrm{g} \cdot \mathrm{kg}^{-1}\right)\end{array}$ & $\begin{array}{l}\text { Total ZEA } \\
\left(\mu \mathrm{g} \cdot \mathrm{kg}^{-1)}\right.\end{array}$ & $\begin{array}{l}\text { Total Mycotoxins } \\
\left(\mu \mathrm{g} \cdot \mathrm{kg}^{-1}\right)\end{array}$ \\
\hline 1 & 129.30 & 8.90 & 16.4 & 1.7 & 242.90 & 581.8 & 30.5 & 979.3 \\
\hline 2 & 139.30 & 8.90 & 17.7 & 2.4 & 271.00 & 479.7 & & 934.6 \\
\hline
\end{tabular}

1, 2 = multiple mycotoxins analysis. 


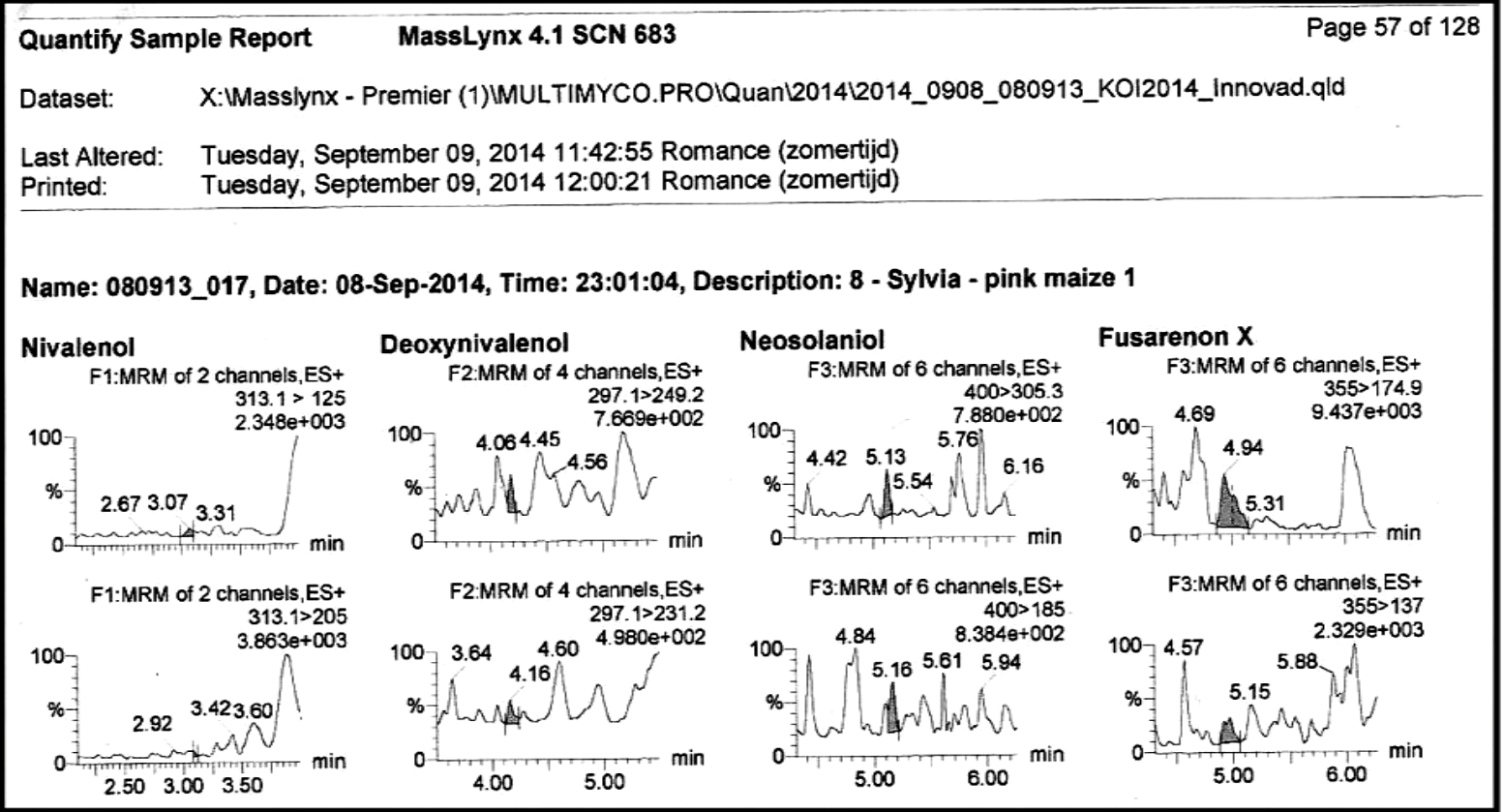

Figure 1. Occurrence of multiple mycotoxin in hybrid seed chemically treated.

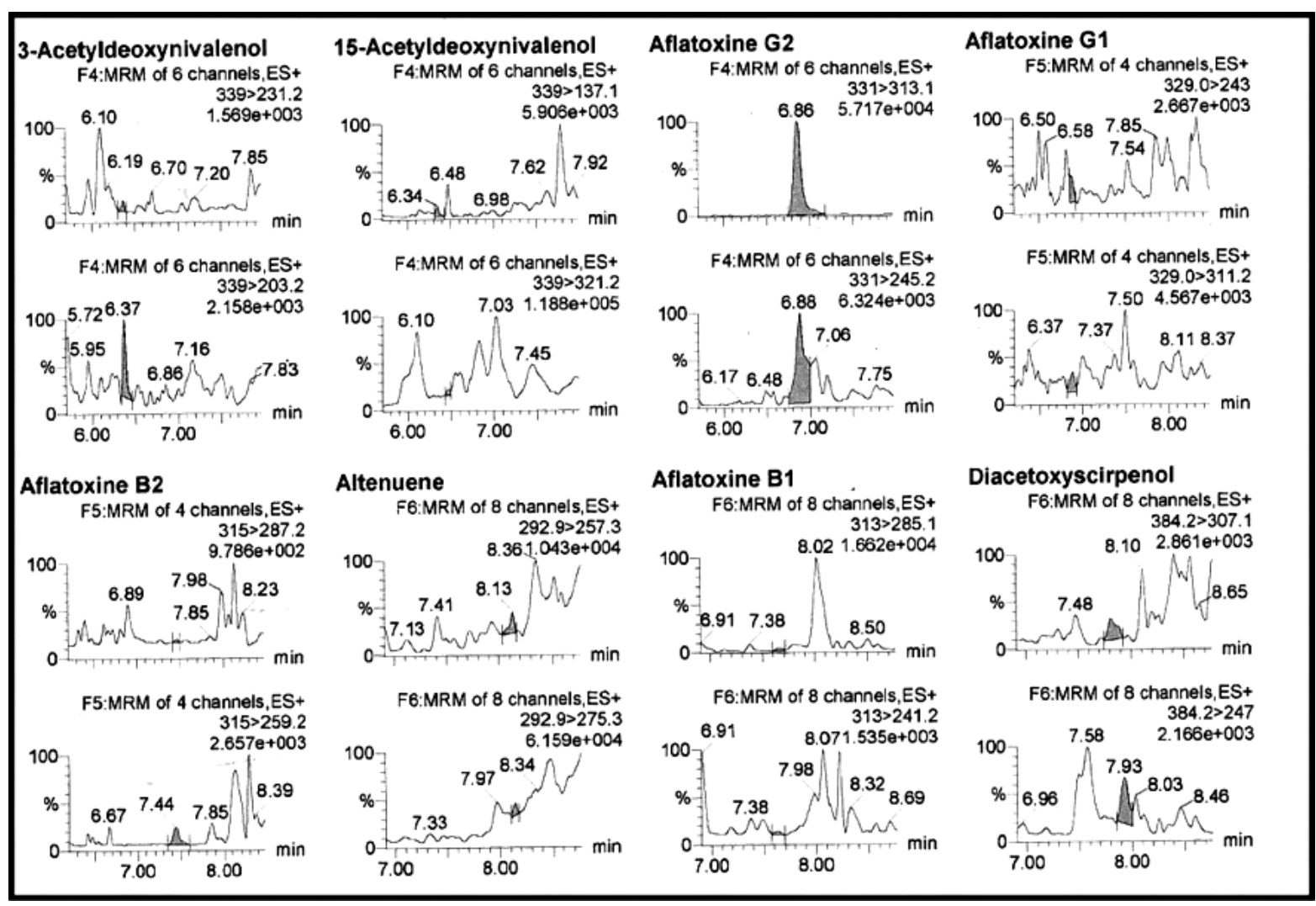

Figure 2. Identification of $\mathrm{AFG}_{2}, \mathrm{AFG}_{1}, \mathrm{AFB}_{2}, \mathrm{AFB}_{1}$ and derivative mycotoxins.

\section{Discussion}

The aflatoxins levels detected in eight samples of chemical treated seed maize in our study were lower from 


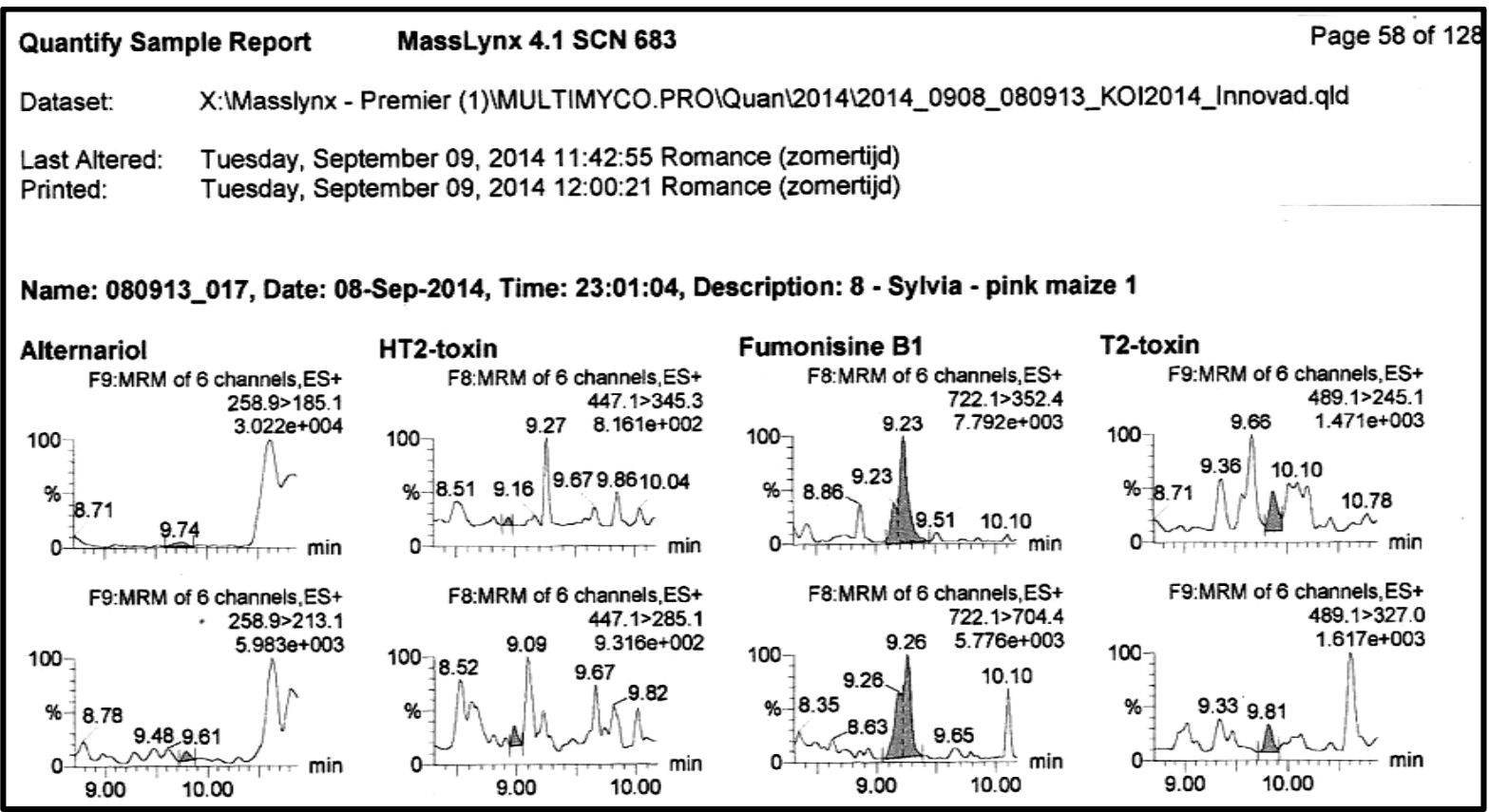

Figure 3. Detection of Alternariol. HT2, Fumonisine $\mathrm{B}_{1}$, and T2.

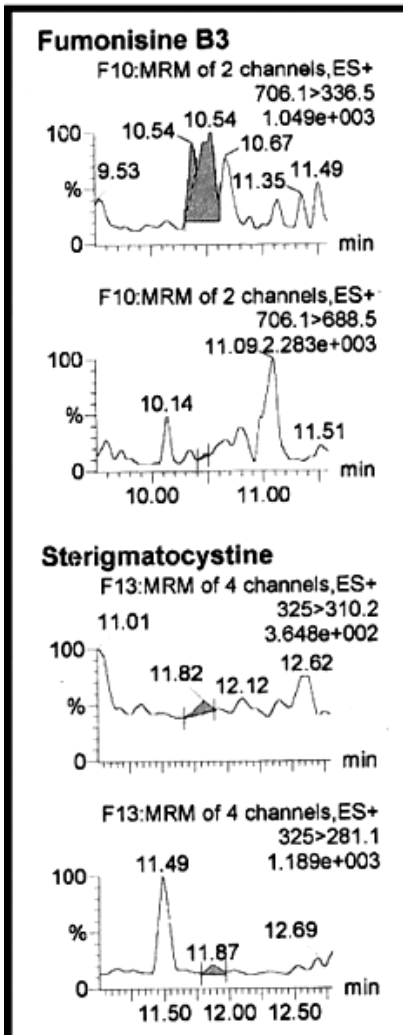

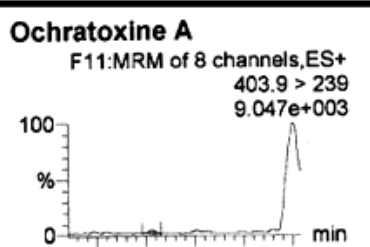

F11:MRM of 8 channels, ES+

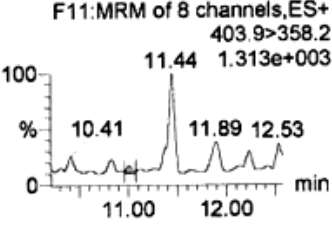

Roquefortine C

F7:MRM of 2 channels, ES+

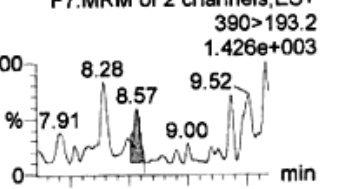

F7:MRM of 2 channels, ES+

$390>322.2$

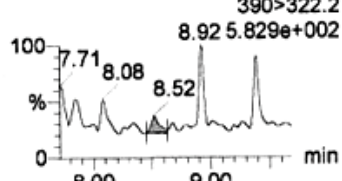

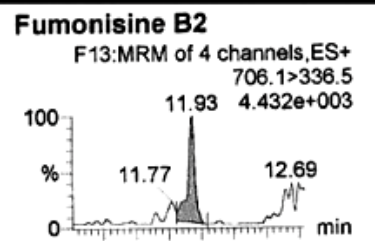

F13:MRM of 4 channels, ES+

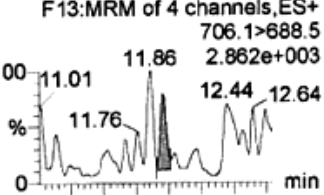

11.5012 .0012 .50
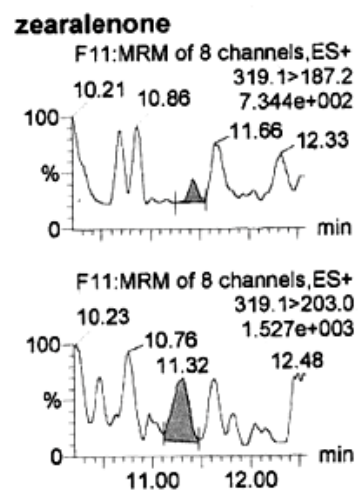

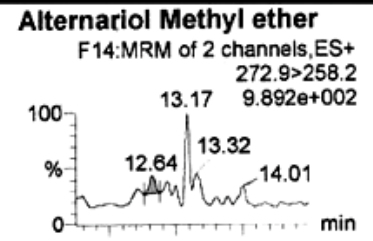

F14:MRM of 2 channels, ES+

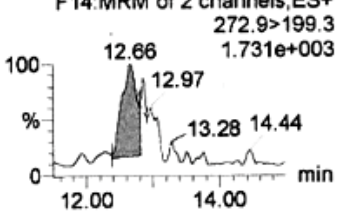

Zearalenone2

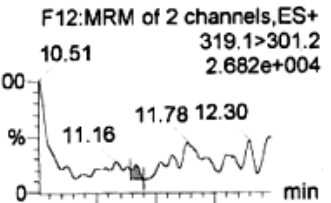

F12:MRM of 2 channels, ES+ $319.1>283.3$ $11.855 .039 e+003$

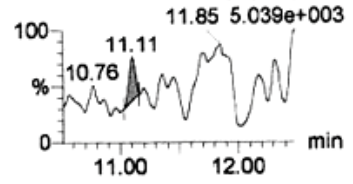

Figure 4. Identification of $\mathrm{FB}_{3}, \mathrm{FB}_{2}$, Zearalenone, Zearalenone2, Ochratoxin A, Sterigmatocistine and Roquefortine C.

detected feed corn used in animal production at Mexico [22]. However, we had an Aflatoxin $\mathrm{G}_{2}$ in the highest content, which was probably due that Aspergillus flavus didn't find the environmental conditions for survival or the subspecies flavus were not produced AFB $_{1}$ [23] [24]. Nevertheless, we found Sterigmatocistine, which might 


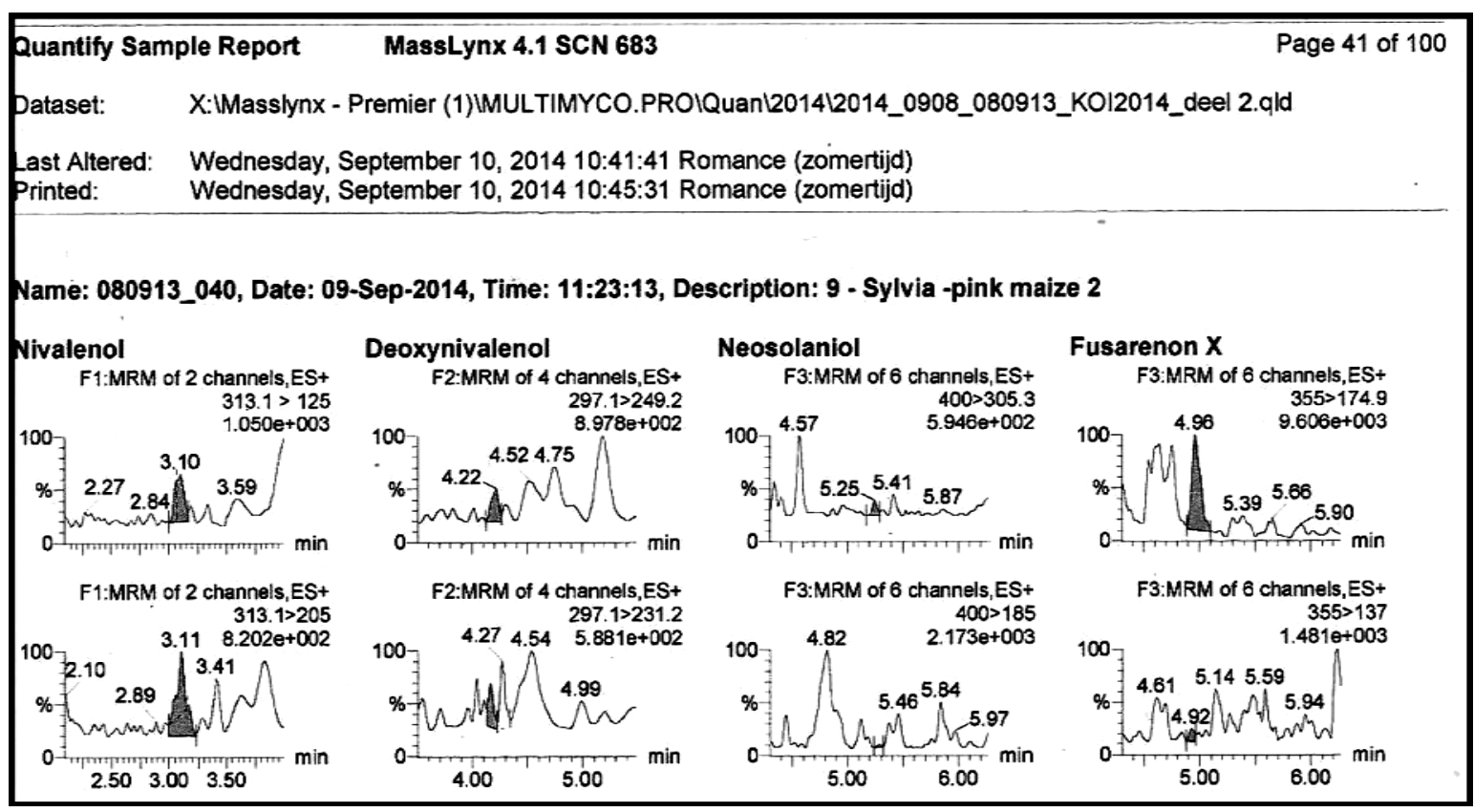

Figure 5. Multiple mycotoxins detection in commercial hybrid seed maize.

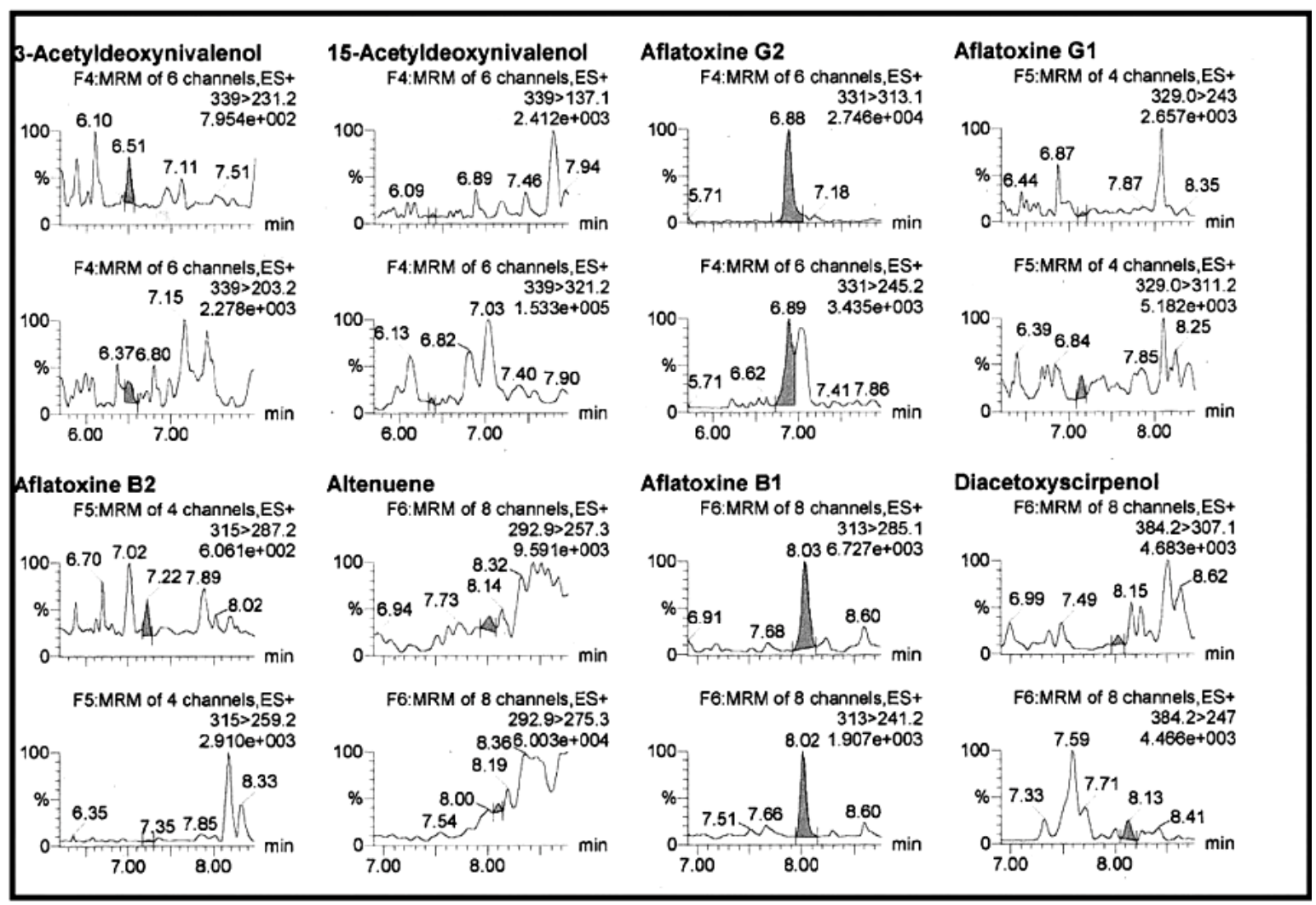

Figure 6. Identification of thricothecene mycotoxins.

be aflatoxins precursor. In Mexico the Fumonisins occurrence in improved corn grain has been noted previously in levels 03 to $64 \mu \mathrm{g} \cdot \mathrm{kg}^{-1}$, and commercial hybrid in $32 \mu \mathrm{g} \cdot \mathrm{kg}^{-1}$ [25]; similar to the found results in the treated seeds, suggesting that the chemical treatment has not been possible to protect the seed against fungus, according 


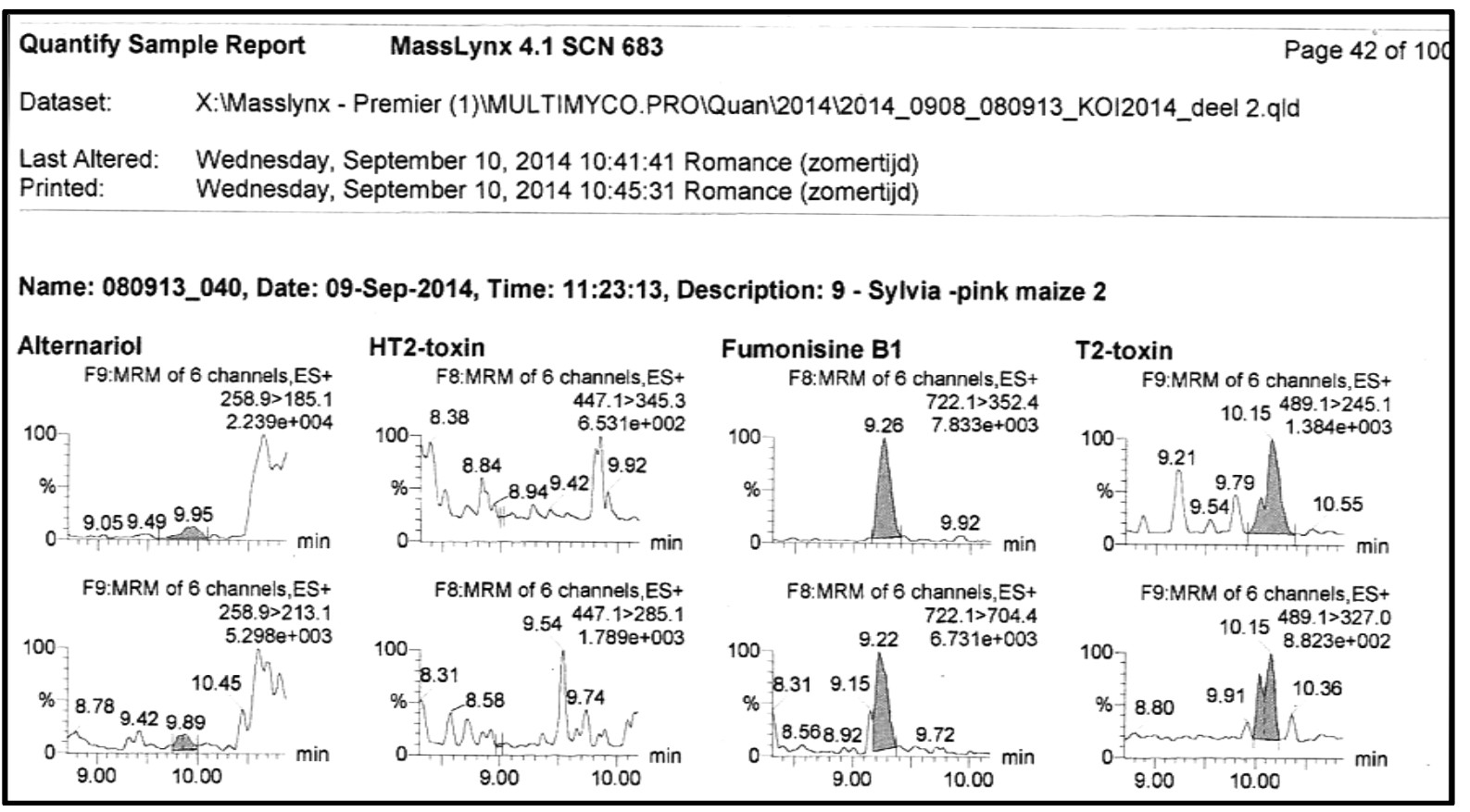

Figure 7. Alternariol, HT2 toxin, FB1, T2 Toxin.

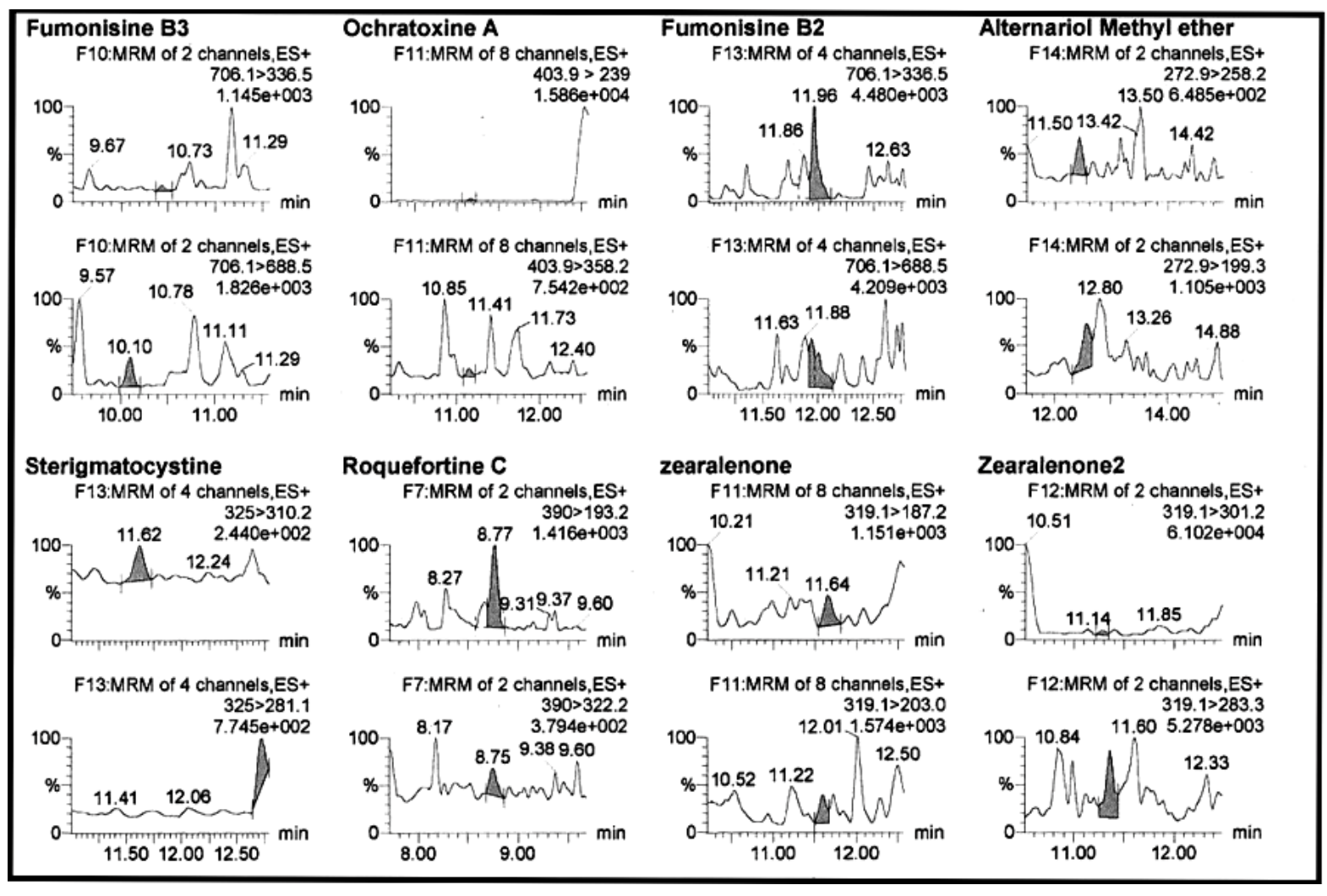

Figure 8. Co-occurrence of eight mycotoxins in commercial seed hybrid maize.

to [26], there is growing evidence that loss of soil biodiversity is a serious issue for arable soils under intensive cultivation. The mycophenolic acid (MPA) [6-(4-hydroxy-6-methoxy-7-methyl-3-oxo-5-phthalanyl)-4-me-thyl4-hexenoic acid] was the higher mycotoxin incidence in both hybrid seed samples, which is related to Penicillium 
roqueforti ubiquitous fungus and known to have antibiotic properties but little known about their natural prevalence in feed and foods for human consumption, contrary has been studied in silage corn in the feeding of dairy cows [27]. The alternariol (AOH) and methyl ethyl alternariol (AME) are mycotoxins produced by Alternaria sp. It is a common saprophyte pathogen of senescent plant residue and in soil, these mycotoxins are detected in soy, it has been notified the co-occurrence AOH in a minimum level of $25 \mu \mathrm{g} \cdot \mathrm{kg}$ and AME in $62 \mu \mathrm{g} \cdot \mathrm{kg}^{-1}$ [28]. All these findings indicate that chemical treated seed maize prior sowing are susceptible to fungus infection and mycotoxins contamination [29]-[31]. The low mycotoxins concentration was due to the extracts purification failure, which could not be removed as interference colorant. It has been mentioned that it is an essential step in the analysis of mycotoxins, especially when chromatographic techniques are used for their determination at trace levels [32].

\section{Conclusion}

The present study has reported for the first time a survey of multiple mycotoxin contamination in two chemically treated hybrids maize seed for sowing in Mexico, although the median concentrations of the analytes were in a low level allowed in the National Legislation. These data about the presence and content of mycophenolic acid, Ochratoxin A, Fumonisins, Nivalenol, Fusarenone X and Alternariol can be used into National Programs of breeding in order to improve the sanitary quality and to investigate the final contamination of agricultural products with multiple mycotoxin contamination.

\section{References}

[1] (2014) Centro de Estudios para el consumo rural sostenible y la soberanía alimentaria. www.cedrssa.gob.mx

[2] Duarte-Vogel, S. and Villamil-Jiménez, L.C. (2006) Micotoxins in Public Health. Revista de Salud Pública, 8, $129-135$. http://dx.doi.org/10.1590/S0124-00642006000400011

[3] Turkington, T.K., Clear, R.M., Demeke, T., Lange, R., Xi, K. and Kumar, K. (2011) Isolation of Fusarium graminearum from Cereal, Grass and Corn Residues from Alberta, 2001-2003. Canadian Journal of Plant Pathology, 33, 179186.

[4] Galvano, F. and Ritieni, A. (2005) Mycotoxins in the Human Food Chain. In: Diez, D., Ed., Mycotoxin Blue Book, Nothinghan University Press, Nothingham, 187.

[5] Naresh, M., Hope, R., Carrns, V. and Aldred, D. (2003) Post-Harvest Fungal Ecology: Impact of Fungal Growth and Mycotoxin Accumulation in Stored Grain. European Journal of Plant Pathology, 109, 723-730. http://dx.doi.org/10.1023/A:1026082425177

[6] International Agency for Research on Cancer (IARC) (1993) IARC Monographs on the Evaluation of Carcinogenic Risks to Humans. Some Naturally Occurring Substances: Food Items and Constituents, Heterocyclic Aromatic Amines and Mycotoxins. Volume 56, IARC Working Group, WHO, Lyon.

[7] Antonissen, G., Martel, A., Pasnans, F., Ducatelle, R., Verbrugghe, E., Vandenbroucke, V., et al. (2014) The Impact of Fusarium Mycotoxin on Human and Animal Host Susceptibility to Infectious Diseases. Toxins, 6, 340-352.

[8] Rajmon, R., Sedmikova, M., Jílek, F., Koubková, M., Härtlová, H., Bárta, I. and Šmerák, P. (2001) Combined Effects of Repeated Low Doses of Aflatoxin B1 and T-2 Toxin on the Chinese Hamster. Veterinary Medicine-Czech, 46, 301307.

[9] Streit, E., Schwab, C., Sulyok, M., Naehrer, K., Krska, R. and Schatzmayr, G. (2013) Multi-Mycotoxin Screening Reveals the Occurrence of 139 Different Secondary Metabolites in Fed and Feed Ingredients. Toxins, 5, 504-523. http://dx.doi.org/10.3390/toxins5030504

[10] Pereyra, S.A. and Dill-Macky, R. (2008) Colonization of the Residues of Diverse Plant Species by Gibberella zeae and Their Contribution to Fusarium Head Blight Inoculum. Plant Disease, 92, 800-807.

[11] Oldenburg, E., Kramer, S., Schrader, S. and Weinert, J. (2008) Impact of the Earthworm Lumbricus terrestris on the Degradation of Fusarium-Infected and Deoxynivalenol-Contaminated Wheat Straw. Soil Biology and Biochemistry, 40, 3049-3053. http://dx.doi.org/10.1016/j.soilbio.2008.09.004

[12] Vogelgsang, S., Hecker, A., Musa, T., Dorn, B. and Forrer, H.-R. (2011) On-Farm Experiments over 5 Years in a Grain Maize/Winter Wheat Rotation: Effect of Maize Residue Treatments on Fusarium graminearum Infection and Deoxynivalenol Contamination in Wheat. Mycotoxin Research, 27, 81- 96. http://dx.doi.org/10.1007/s12550-010-0079-y

[13] Lee, H.B., Patriarca, A. and Magan, N. (2015) Alternaria in Food: Ecophysiology, Mycotoxin Production and Toxi- 
cology. Mycobiology, 43, 93-106. http://dx.doi.org/10.5941/MYCO.2015.43.2.93

[14] Carrillo, M.G.V., Pérez Camarillo, J.P., Hernández Casillas, J.M., de la Luz Marrufo Diaz, M. and Ruiz, E.M. (2010) Calidad de granos y tortillas de maíces criollos del Altiplano y Valle del Mezquital, México. Revista Fitotecnia Mexicana, 33, 49-56.

[15] Peña, B.S. (2006) Detection of Fumonisins in Maize (Zea mays L.) by Three Analytical Techniques (HPLC, TLC and ELISA). In: Njapau, H., Sócrates, T., van Egmond, H. and Park, D., Eds., Mycotoxins and Phycotoxins Advances in Determination, Toxicology and Exposure Management, Wageningen Academic Publishers, The Netherlands.

[16] SAGARPA, Secretaría de Agricultura, Ganadería, Desarrollo Rural, Pesca y Alimentación (2002) Norma Mexicana NMX-FF-034/1-SCFI-2002. Productos alimenticios no industrializados-para consumo humano—cereales—maíz blanco para proceso alcalino para tortilla de maíz y productos de maíz nixtamalizado-Especificaciones y métodos de prueba. Dirección General de Normas, SAGARPA, México, D. F. 18 p.

[17] The Commission of the European Communities (EC) (2006) Commission Regulation (EC) No. 1881/2006 of 19 December 2006 Setting Maximum Levels for Certain Contaminants in Foodstuffs. Official Journal of the European Union, L364, 4-24.

[18] The Commission of the European Communities (EC) (2010) Commission Regulation (EU) No. 1052010 Amending Regulation (EC) No. 1881/2006 Setting Maximum Levels for Certain Contaminants in Foodstuffs as Regards Ochratoxin A. Official Journal of the European Union, L035, 7-8.

[19] EFSA (2006) Opinion of the Scientific Panel on Contaminants in Food Chain on a Request from the Commission Related to Ochratoxin A in Food. EFSA Journal, 365, 1-56.

[20] De Saeger, S. (2011) Determining Mycotoxins and Mycotoxigenic Fungi in Food and Feed. WP Series in Food Science, Technology and Nutrition, Philadelphia.

[21] Horwitz, W. (2002) Official Methods of Analysis of AOAC International. 17th Edition, AOAC International, Gaithersbourd.

[22] Espinoza, P.N., Garrido, R.E. and Pérez, S.M. (2003) Cuantificación de cuatro micotoxinas en el grano de maíz en el estado de Chiapas. Proceedings of I Panamerican Symposium on mycotoxins for industry, México City.

[23] Flores, O.C.M., Hernández, P.L.B. and Vázquez, M.J. (2006) Mycotoxin Contamination of Grains and Feeds Used in Animal Production in Mexico during 2003. Técnica Pecuaria México, 247-256.

[24] Cotty, P.P. and Jaime García, R. (2007) Influence of Climate in Aflatoxin Producing Fungi and Aflatoxin Contamination. International Journal of Food Microbiology, 119, 109-115. http://dx.doi.org/10.1016/j.ijfoodmicro.2007.07.060

[25] Barberis, M.G., Giaj, G.M. and Reynoso, M.M. (2014) Factors Affecting Distribution and Abundance of Aspergillus Section Nigri in Vineyard Soils from Grape Growing Regions of Argentina. Journal of the Science of Food and Agriculture, 14, 3001-3007. http://dx.doi.org/10.1002/jsfa.6647

[26] Schrader, S., Wolfarth, F. and Oldenburg, E. (2013) Biological Control of Soil-Borne Phytopathogenic Fungi and Their Mycotoxins by Soil Fauna. Bulletin UASMV Serie Agriculture, 70, 291-298.

[27] Driehuis, F., Spanjer, M.C., Scholten, J.M. and Giffel, M.C. (2008) Occurrence of Mycotoxins in Feedstuffs of Dairy Cows and Estimation of Total Dietary Intakes. Journal of Dairy Science, 91, 4261-4271. http://dx.doi.org/10.3168/jds.2008-1093

[28] Oviedo, M.S., Barros, G.G., Chulze, S.N. and Ramirez, M.L. (2012) Natural Occurrence of Alternariol and Alternariol Monomethyl Ether in Soya Beans. Mycotoxin Research, 28, 169-174. http://dx.doi.org/10.1007/s12550-012-0132-0

[29] Peña, B.S.D. and Carvajal, M.M. (2004) Fumonisins determination in hybrid maize. 1er curso Nacional sobre micotoxinas para la industria, México, D.F.

[30] Munlvold, G.P. and Mara, J.K. (2002) Laboratory and Growth Chamber Evaluation of Fungicidal Seed Treatments for Maize Seedling Blight Caused by Fusarium Species. Plant Disease, 82, 143-150.

[31] Galperin, M., Graf, S. and Kenigsbuch, D. (2003) Seed Treatment Prevents Vertical Transmission of Fusarioum moniliforme Making a Significant Contribution to Disease Control. Phytoparasitica, 31, 344-352. http://dx.doi.org/10.1007/BF02979805

[32] Pascale, M.N. (2009) Detection Methods for Mycotoxins in Cereal Grains and Cereal Products. Zbornik Matice srpske za prirodne nauke, 117, 15-25. http://dx.doi.org/10.2298/zmspn0917015p 